\title{
Lincolnshire borehole proves greater extent of the Scarborough Formation (Jurassic: Bajocian)
}

\author{
M.J. BRADSHAW \& R.H. BATE \\ Department of Geological Sciences, University of Aston, Birmingham, B4 7ET \& \\ Department of Palaeontology, British Museum (Natural History), Cromwell Road, London, SW7 5BD
}

\begin{abstract}
The ostracod fauna of a thin unit of shelly mudstones encountered directly beneath the Great Oolite Group in a recently drilled borehole in north Lincolnshire confirms the presence of the Scarborough Formation, formerly thought of as being confined to the Cleveland Basin. Sandstones and coals separating the Scarborough Formation from typical upper Lincolnshire Limestone calcarenites were probably deposited by delta progradation and are correlated with the regressive Yons Nab Beds and lower Gristhorpe Member of the Cleveland Basin.

Discovery of the Gristhorpe Member and the Scarborough Formation beneath the basal Great Oolite unconformity on the East Midlands Shelf suggests that the youngest limestone facies of the Lincolnshire Limestone can be no younger than earliest sauzei Zone, and that the erosional event which preceded deposition of the Great Oolite is of late humphriesianum Zone or younger age.

A revised palaeogeography for Scarborough Formation times envisages that following initial westward marine transgression along the axis of the Cleveland Basin, the sea broadened and at its maximum extent covered much of the Market Weighton Block.
\end{abstract}

\section{INTRODUCTION}

Between the early Aalenian Dogger Formation and the early Callovian Cornbrash Limestone in the Cleveland Basin is a series of thick fluvio-deltaic sandstones and mudstones separated by four thinner, shallow marine deposits, which together compose the Ravenscar Group. Middle Jurassic strata attenuate southward toward the East Midlands Shelf and are missing over much of the Market Weighton Block due to both syndepositional thinning and later erosion, but they reappear on north Humberside and thicken southward through Lincolnshire (see Fig. 1 for locations and structural setting). The Bajocian of Lincolnshire consists mainly of compositionally variable but dominantly oolitic limestones, and northward advances of the Lincolnshire Limestone Sea account for the medial two marine units of the Cleveland succession. At outcrop, however, the topmost Lincolnshire Limestone (Inferior Oolite Group) is of early Bajocian laeviuscula Subzone or slightly younger age (Ashton, 1980; Ashton \& Parsons, in press), and is separated by an erosional unconformity from sandstones and mudstones of the basal Upper Estuarine "Series" (Great Oolite Group), which have not been biostratigraphically dated but are thought to be of late Bajocian or earliest Bathonian age (Bradshaw, 1978). No marine representative of the Scarborough Formation, the youngest marine unit within the Ravenscar Group of North Yorkshire (Fig. 2) and of ?late sauzei to humphriesianum Zone age (Parsons, 1977) has been recognised on the East Midlands Shelf (throughout this article, Zone or Subzone used without qualification refers to ammonite biozones which are regarded as tantamount to chronozones; Torrens, 1980). It was therefore with great surprise that a recently drilled borehole at Nettleton, north Lincolnshire (Grid Ref. TF 12459823), some $17 \mathrm{~km}$ east of the Bajocian outcrop, cored a sandy and argillaceous sequence between typical upper Lincolnshire Limestone and basal Upper Estuarine "Series", which includes beds whose macrofaunas resemble those of the Scarborough Formation. This paper presents a detailed description and interpretation of the upper Lincolnshire Limestone to basal Upper Estuarine "Series" succession at Nettleton, and important biostratigraphic confirmation of age using the ostracod fauna. The effect of the Scarborough Formation's discovery in Lincolnshire on our understanding of Middle Jurassic sedimentation patterns is also discussed.

\section{SEDIMENTOLOGY AND PALAEONTOLOGY}

Lincolnshire Limestone stratigraphy has been reviewed by Kent (1966) and recently revised by Ashton $(1975,1980)$. On south Humberside the formation is split informally into a lower unit of oolitic and bioclastic, often micritic limestones with varying terrigenous content (Kirton Beds), and an upper, coarser, often crossbedded bioclastic oolite (Hibaldstow Beds). The Kirton Beds contain a medial argillaceous unit (Raventhorpe Member of Ashton, 1975), which reflects a phase of southward progradation of the Yorkshire Delta. A lower 


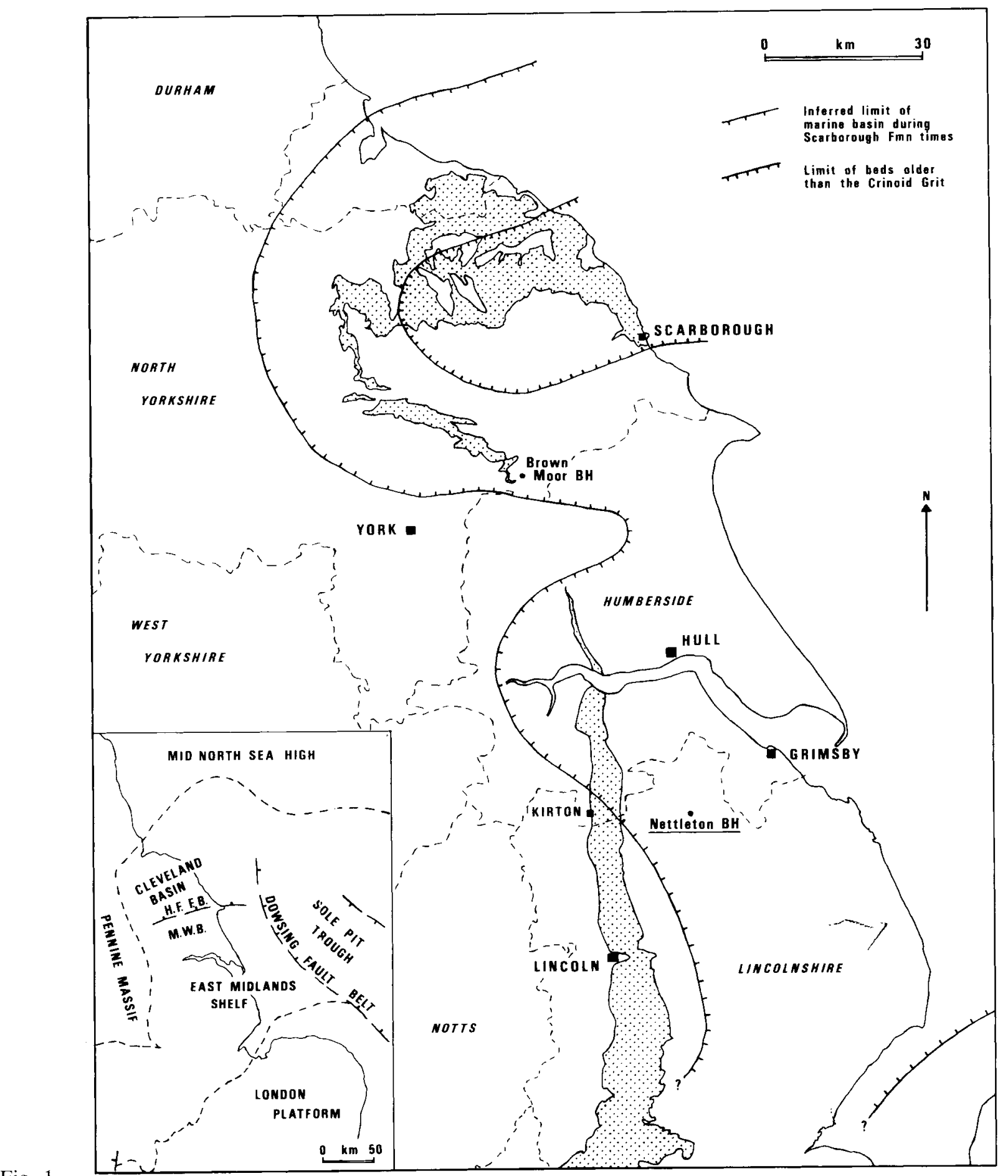

Fig. 1

limestone tongue continues into the Cleveland Basin as the marine Blowgill Beds (Bate, 1967; Hemingway, 1974) whilst an upper limestone tongue, the Cave Oolite, lateral equivalent of the Hibaldstow Beds and also the upper Kirton Beds, persists as the Cayton Bay Formation (of Parsons, 1980; Lebberston Member of Hemingway and Knox, 1973).
An account of the lower and middle Lincolnshire Limestone at Nettleton is contained in Bradshaw \& Penney (1982). The Raventhorpe Member and associated beds are more terrigenous than in their type section at Kirton-in-Lindsey (see Ashton, 1975), suggesting a stronger deltaic influence. The Hibaldstow Beds are themselves unexceptional, but instead of being directly 


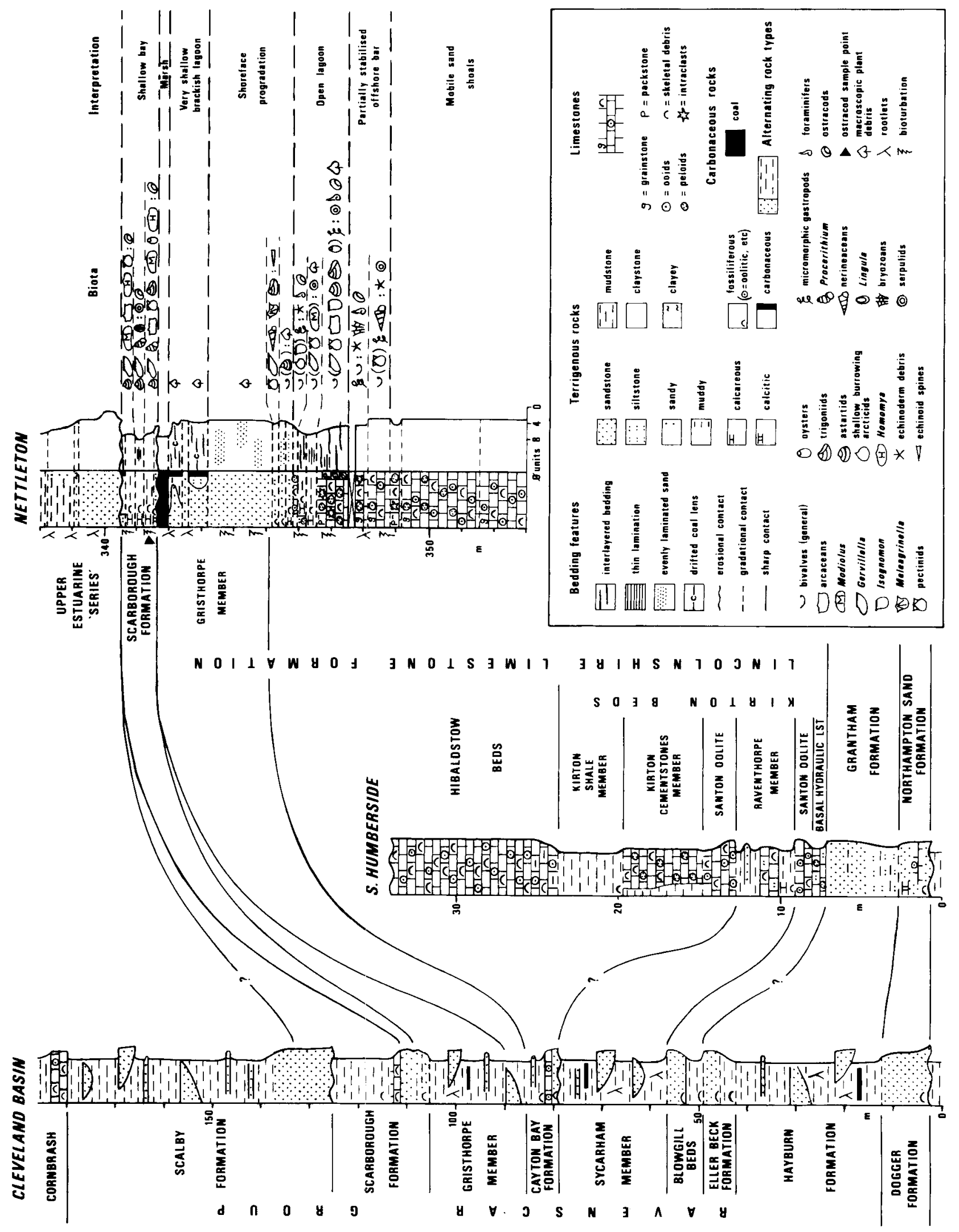


and unconformably overlain by the Upper Estuarine "Series", they grade up into the sandy and argillaceous sequence illustrated by Fig. 2. Moderately sorted calcarenites containing ooids and subordinate bioclasts become finer grained, very poorly sorted and strongly bioturbated, and contain a high proportion of coarse silt to very fine sand grade peloidal material, much of which is probably of faecal origin. This transition is accompanied by the appearance of large numbers of medium to coarse sand-sized peloids and structureless cryptocrystalline intraclasts, reflecting an increase in ooid and skeletal micritization. Intraclasts of quartz-silty wackestone also occur and skeletal debris is mainly of molluscan origin; gastropods (including micromorphic forms) and pectinids are especially abundant, but ostracods and benthic foraminifera are also very common. Grainstones give way upward to darker argillaceous packstones and then variably calcareous and carbonaceous dark grey mudstones; thin layers of coarser oolitic material are common. This upward increase in mud content is accompanied by a higher proportion of whole shells; bivalves dominate, mostly pteriaceans (Gervillella, Isognomon) and pectinids (both thin-shelled Propeamussium (Parvamussium) and thicker shelled Camptonectes), but shallow burrowing genera (astartids and articids) form a significant minor element and gastropods and serpulids are common. Within the overlying greenish grey to light olive grey siltstones and sandstones an abundant macrofauna of pectinids (again mostly P. (Parvamussium)) and "Astarte" minima (Phillips), accompanied by Gervillella, Meleagrinella cf. lycetti (Rollier), ? Trigonia and high spired gastropods is lost upward whilst macroscopic plant debris remains abundant. Though intensely bioturbated in places, the sandstones display even lamination with rare low angle erosion surfaces, and contain carbonaceous and micaceous siltstone interlaminae. Thin coal layers occur toward the top of the sandstones, which are followed by thinly interlayered very fine sandstone, dark carbonaceous mudstone and minor coal, with rootlets penetrating down from a capping pyritic coal seam. The latter is $27 \mathrm{~cm}$ thick and becomes muddy upward, grading into $3 \mathrm{~cm}$ of thinly interlayered carbonaceous mudstone and light olive grey siltstone before an important erosion surface at $341.69 \mathrm{~m}$. Very light grey unfossiliferous sand-filled burrows extend up to $12 \mathrm{~cm}$ below but are truncated by this surface; they indicate that sandstone originally followed the interlayered lithology.

The greenish grey calcitic siltstone above the erosion surface contains thick -shelled bivalve debris, including oysters, and fines upward into medium grey and olive grey mudstones and claystones. These beds contain a very well preserved macrofauna with extraordinary numbers of 'Astarte' minima and Gervillella acuta (J. de C. Sowerby), common Cuccullea cancellata Phillips (probably a Grammatodon) and Procerithium, also Modiolus, Camptonectes, oysters (cf. Praeexogyra),
Trigonia, Nicaniella (Pressastarte), ? Homomya, Lingula and serpulids. A low diversity ostracod fauna (sampled between 341.47 and $341.49 \mathrm{~m}$, and contained on faunal slide number MPA 17235 in the Institute of Geological Sciences Collections, Leeds, consists of Malzia unicarinata Bate, $M$. bicarinata Bate, Praeschuleridea subtrigona intermedia Bate, Fuhrbergiella (Fuhrbergiella) horrida horrida Brand \& Malz and Glyptocythere scitula Bate. The mudstones are strongly bioturbated and contain a relatively high proportion of articulated bivalves. Bioturbation is less intense in the claystones where shell plasters frequently display large numbers of similarly orientated Gervillella valves and Procerithium. $15 \mathrm{~cm}$ of thinly interlayered siltstone and carbonaceous claystone, lacking a calcareous macrofauna, caps this thin $(1.17 \mathrm{~m})$ marine sequence beneath a second sharp contact at $340.52 \mathrm{~m}$. The beds above the contact are easily recognisable as the basal Upper Estuarine "Series".

Typically in the East Midlands, the Upper Estuarine "Series" is divisible into two, a lower rootletted finingupward sequence of white, yellowish grey and olive grey sandstones and siltstones and brown, black and green clay tones, lacking a calcareous macrofauna, succeeded by a stack of vertically repetitive sequences or rhythms, each with an erosive bivalve-rich base and a rootletted top (Bradshaw, 1978). At Nettleton, only the lower member appears to be present. Sandstones fine upward into mudstones and claystones of varying shades of green and brown; black, intensely carbonaceous layers also occur and the sequence is rootletted throughout. Only the base of the Upper Estuarine "Series" is illustrated in Fig. 2, and the reader is referred to Bradshaw \& Penney (1982) for the rest of the Great Oolite succession.

\section{STRATIGRAPHY}

The Hibaldstow Beds of north Lincolnshire and south Humberside pass north of the Humber into the Cave Oolite, a limestone tongue laterally equivalent to the marine Cayton Bay Formation of the Cleveland Basin (Bate, 1967; Parsons, 1980). Hence the section encountered above the Hibaldstow Beds and below the Upper Estuarine "Series" at Nettleton, with its rootletted sandstones and coal followed by a thin marine unit, invites a lithostratigraphic correlation with strata following the Cayton Bay Formation in Yorkshire, namely the deltaic Gristhorpe Member (of the Cloughton Formation) and the overlying marine Scarborough Formation.

The abundance of Gervillella acuta, 'Astarte' minima and Cucullaea cancellata within the marine unit at Nettleton is reminiscent of the Scarborough Formation, in particular the Hundale Shale Member (of Parsons, 1977) on the Yorkshire coast, but the ostracod fauna, whilst confirming a Scarborough Formation age, suggests a time correlation with beds at the top of or slightly 
above the Hundale Shale. The abundance of Malzia unicarinata in association with $M$. bicarinata and Glyptocythere scitula indicates the topmost part of the Glyptocythere polita ostracod Biozone (of Bate, 1965, 1978 ). The boundary between the $G$. polita and succeeding $G$. scitula ostracod Biozones, as established by Bate (1965), is recognised by the last occurrence of species characteristic of the $G$. polita Biozone rather than the first appearance of $G$. scitula. In the celebrated coastal section at Hundale Point near Scarborough (TA 026948), one of us (Bate, 1965) placed the base of the $G$. scitula Biozone below a thick fossiliferous sandstone known as the Crinoid Grit (bed 14 of Bate, 1965; = bed 12, the upper part of the Crinoid Grit Member of Parsons, 1977). However, as no ostracods were actually obtained from this unit, the zonal boundary could, with equal justification, have been placed above the Crinoid Grit within the shales of the Spindle Thorn Limestone Member (of Parsons, 1977). The ostracod biostratigraphies of the sections at Ravenscar (NZ 988012) and other investigated localities where the Crinoid Grit is present (Bate, 1965) are similarly equivocal, and we conclude that this distinctive unit is approximately age equivalent to the Nettleton beds. Ammonite evidence indicates that all three Subzones (romani, humphriesianum and blagdeni) of the Lower Bajocian humphriesianum Zone are represented in the upper half of the Scarborough Formation of the Yorkshire coast, above the Crinoid Grit (Parsons, 1977). The lower part of the formation, including the Crinoid Grit, is therefore either of romani Subzone age or may belong to the upper sauzei Zone. Bate's (1965) concept of the regional palaeogeography in Scarborough Formation times, that of a shallow marine embayment centred along the axis of the Cleveland Basin and opening to the east, was supported by Parsons (1977). However, the evidence for closure to the south with a peripheral zone of sandstone deposition was based only on one incomplete exposure (Stonecliff Wood, SE 743676; Bate, 1965 ) and the Fordon No. 1 Borehole (SE 05857575; Falcon \& Kent, 1960), which was not cored. A recent borehole, sited within the Howardian-Flamborough Fault Belt on the margin of the Cleveland Basin (at Brown Moor, SE 81266203; Gaunt et al., 1980), encountered $2.8 \mathrm{~m}$ of fossiliferous Scarborough Formation in a mainly mudstone facies, and requires that the configuration of the proposed embayment be modified (see below). We believe that the faunal content and sedimentological setting of the thin Scarborough Formation equivalent at Nettleton indicates original physical continutity with the Scarborough Formation of Yorkshire, and hence justifies the use of this lithostratigraphic name for the highest beds of the Inferior Oolite Group in Lincolnshire.

The rootletted sandstones and coal beneath the Scarborough Formation at Nettleton must signify the same regression as that represented by the Gristhorpe
Member in the Cleveland Basin, and original physical continuity can be reasonably inferred. The upper part of the Cayton Bay Formation on the Yorkshire coast consists of the Yons Nab Beds, a highly variable but mostly sandy and poorly calcareous unit which is differentiated from the overlying Gristhorpe Member sandstones and mudstones by the presence of a marine bivalve and echinoderm macrofauna (Bate, 1959, 1967; Livera \& Leeder, 1981). Using this criterion, the base of the Gristhorpe Member at Nettleton should be drawn within sandstone at a depth of $345.15 \mathrm{~m}$ (Fig. 2). The Gristhorpe Member hence becomes the uppermost unit of the Lincolnshire Limestone Formation, and in its sandy and argillaceous nature is comparable to the stratigraphically lower Raventhorpe Member. The $2.56 \mathrm{~m}$ of muddy limestones, mudstones and siltstones between the Gristhorpe Member and typical upper Lincolnshire Limestone are provisionally included in the Hibaldstow Beds, though a much-needed thorough investigation of the upper Lincolnshire Limestone north of Lincoln may result in their separation as a formal member.

\section{FACIES INTERPRETATION}

The commonly cross-bedded skeletal and oolitic calcarenites and calcirudites (grainstones) of the upper Lincolnshire Limestone are moderate to high energy deposits which probably formed in a complex of mobile sand shoals in water depths of up to $10 \mathrm{~m}$ (Standard Facies Belt 6 of Wilson, 1975). At Nettleton, the gradual upward passage from these limestones through mudstones to siltstones and sandstones capped by coal clearly indicates coastal progradation (Fig. 2). Within the lime grainstones at the base of the sequence, the upward increase in skeletal and ooid micritization is taken to indicate slowing rates of carbonate production, probably in response to increasing water turbidity caused by suspended terrigenous mud. Bioturbation increases upward and sorting worsens due to the admixture of faecal pellets. The occurrence of plant rootlets near the top of the grainstones suggests very shallow or emergent conditions, possibly near the crest of an offshore bar. The succeeding argillaceous packstones and claystones accumulated on the landward side of the bar and contain thin washover layers of sand-grade peloidal and micritized oolitic material. The low diversity bivalvedominated macrofauna suggests a fairly high stress environment, and the lack of stenohaline taxa such as corals and brachiopods, also the paucity of echinoderm remains, points to fluctuating and probably reduced salinities. Abundant suspension-feeders, including shallow burrowing forms, indicate a stable substrate and sufficient water turbulence to carry suspended organic matter. Shoreface progradation is represented by a coarsening-upward from muddy lithologies to bioturbated sandstones. The overlying interlayered sand- 
stones and carbonaceous mudstones contain thin drifted coals and are remarkably poorly bioturbated; they are penetrated by the well-developed root foundation of a capping coal seam and were probably deposited in a very shallow brackish lagoon.

The Scarborough Formation at Nettleton has a sharp erosive base, and has removed an unknown thickness of Gristhorpe Member sediments. The macrofauna of the mudstones and claystones is dominated by non-siphonate epifaunal and shallow infaunal suspension-feeding bivalves, and is comparable to the upper Hibaldstow Beds fauna in its rather low diversity and lack of stenohaline taxa. Dinoflagellate cysts are rare and the microplankton consists largely of acanthomorph and sphaeromorph acritarchs, indicating a marginal marine setting; common Botryococcus reveals some input from freshwater/?brackish environments (Fenton, in Bradshaw \& Penney, 1982), Shell plasters of aligned Gervillella valves and Procerithium reflect episodes of increased wave or current activity, perhaps associated with storms.

Age-equivalents of the upper Scarborough Formation of Yorkshire are absent at Nettleton, and if deposited were probably removed by pre-Upper Estuarine "Series" erosion. Regional analysis of the lower part of the Upper Estuarine "Series" suggests initially isolated lakes which coalesced with rise in lake level and were then infilled, with the development of a broad marsh drained by small mixed load channels (Bradshaw, 1978).

\section{CONCLUSIONS}

The discovery of the Gristhorpe Member and the Scarborough Formation beneath the Chalk Wolds of north Lincolnshire has implications for the age of the Lincolnshire Limestone Formation at outcrop. The known ammonite faunas of the Lincolnshire Limestone span the discites and laeviuscula Zones of the Lower Bajocian (Ashton \& Parsons, in press; Ashton, 1980; Parsons, 1980), but the highest member at outcrop, the calcarenitic Clipsham Member (of Ashton, 1980), has not yet yielded ammonites. However, as the Scarborough Formation at Nettleton is either of earliest humphriesianum Zone age or belongs to the upper sauzei Zone, and is preceded by a regressive sequence with sands and coals, then the youngest limestone facies of the Lincolnshire Limestone can be no younger than earliest sauzei Zone.

Bearing in mind the interpretation of correlative strata in the Cleveland Basin (Hemingway, 1974; Livera \& Leeder, 1981), the upper Hibaldstow Beds and Gristhorpe Member at Nettleton were probably deposited in a deltaic milieu by delta front progradation followed by the establishment of a lower deltaic plain. Fluvialdominated upper deltaic plain sediments, which form the bulk of the Gristhorpe Member in Yorkshire (Livera \&. Leeder, $o p$. cit.), are absent at Nettleton, but may have been removed prior to or during the Scarborough Formation transgression.

In addition to revealing the wide spread of the Gristhorpe Member regression, the Nettleton Borehole has disclosed a much greater extent of the Scarborough Formation than formerly thought. The marine transgression at Nettleton appears to have coincided with deposition of the Crinoid Grit in Yorkshire. This latter unit overlaps older Scarborough Formation beds away from the axis of the Cleveland Basin (Bate, 1965; Livera \& Leeder, 1981). The speculative reconstruction in Fig. 1 of the limits of the marine basin during Scarborough Formation times takes into account biostratigraphical and sedimentological evidence for initial westward transgression along the axis of the Cleveland Basin from the Sole Pit Trough (Bate, 1965; Parsons, 1977). The ammonite fauna supports a stronger marine connection to northern Germany than to southern England (Parsons, op. cit.), and therefore any seaway across central England between the London Platform and the Pennine Massif must have been shallow and restricted. The Nettleton discovery suggests that, contrary to the views of Hemingway (1974) and Gaunt et al. (1980), the Market Weighton area could have been at least partially submerged on its eastern flank during the maximum extent of the Scarborough Formation sea, though the abundance of plant debris in the Brown Moor section (Gaunt et al., 1980) indicates the proximity of land, perhaps connected westward to an emergent Pennine Massif.

Finally, the Scarborough Formation's preservation at Nettleton indicates that the erosional event which preceded deposition of the overlying Upper Estuarine "Series" on the East Midlands Shelf is of late humphriesianum Zone or younger age. The resultant unconformity is believed to be continuous with the well known unconformity at the base of the Upper Inferior Oolite over southern England (Bradshaw, 1978).

\section{ACKNOWLEDGEMENTS}

The Nettleton Borehole was drilled as part of the Oxford University Heat Flow project, and M.J.B. thanks Prof. E. R. Oxburgh and Drs. S.R. Penney and S. Richardson for allowing access to the core, which is now housed at the I.G.S., Leeds. 


\section{REFERENCES}

Ashton, M. 1975. A new section in the Lincolnshire Limestone of south Humberside and its significance. Proc. Yorks. geol. Soc., 40, 419-29.

Ashton, M. 1980. The stratigraphy of the Lincolnshire Limestone Formation (Bajocian) in Lincolnshire and Rutland (Leicestershire). Proc. Geol. Ass., London, 91, 203-23.

Ashton, M. \& Parsons, C.F. (In press). Ammonites from the Lincolnshire Limestone Formation (Bajocian) of eastern England. Palaeontology, London.

Bate, R.H. 1959. The Yons Nab Beds of the Middle Jurassic of the Yorkshire Coast. Proc. Yorks. geol. Soc., 32, 153-64, pl. 3.

Bate, R.H. 1965. Middle Jurassic ostracoda from the Grey Limestone Series, Yorkshire. Bull Br. Mus, nat. Hist., London, (Geol.) 11, 75-133, pls. 1-21.

Bate, R.H. 1967. Stratigraphy and palaeogeography of the Yorkshire Oolites and their relationship with the Lincolnshire Limestone. Bull. Br. Mus, nat. Hist., London, (Geol.) 14(4), 111-41.

Bate, R.H. 1978. The Jurassic. Part II: Aalenian to Bathonian. In Bate, R.H. \& Robinson, E. (Eds.), A stratigraphical index of British Ostracoda, Geol. J. Spec. Iss., 8, 213-258. Seel House Press, Liverpool.

Bradshaw, M.J. 1978. A facies analysis of the Bathonian of eastern England. Unpub. D. Phil. thesis, Univ. Oxford.

Bradshaw, M.J. \& Penney, S.R. 1982. A cored Jurassic sequence from north Lincolnshire, England: stratigraphy, facies analysis and regional context. Geol..

Mag., London, 119, 113-228.

Dunham, R.J 1962. Classification of carbonate rocks according to depositional texture. In Ham, W.E. (Ed.) Classification of Carbonate Rocks, Am. Ass. Petrol. Geol., Mem. 1, 108-121.

Falcon, N.L. \& Kent, P.E. 1960. Geological results of petroleum exploration in Britain 1945-1957. Mem. Geol. Soc. Lond., 2, 1-56.
Folk, R.L. 1974. Petrology of Sedimentary Rocks. 2nd Edition, 182 pp. Hemphill's, Austin, Texas.

Gaunt, G.D., Ivemey-Cook, H.C., Penn, I.E. \& Cox, B.M. 1980. Mesozoic rocks proved by I.G.S. boreholes in the Humber and Acklam areas. Rep. Inst. Geol. Sci., 79/13.

Hemingway, J.E. 1974. Jurassic. In Rayner, D.H. \& Hemingway, J.E. (Eds.), The Geology and Mineral Resources of Yorkshire, pp. 161-222. Yorks. Geol. Soc.

Hemingway, J.E. \& Knox, R.W.O'B. 1973. Lithostratigraphical nomenclature of the Middle Jurassic strata of the Yorkshire Basin of north-east England. Proc. Yorks. geol. Soc., 39, 527-35.

Kent, P.E. 1966. The classification and nomenclature of the Lincolnshire Limestone. Trans. Leicester lit. phil. Soc., 60, 57-69.

Livera, S.E. \& Leeder, M.R. 1981. The Middle Jurassic Ravenscar Group ("Deltaic Series") of Yorkshire: recent sedimentological studies as demonstrated during a Field Meeting, 2-3 May 1980. Proc. Geol. Ass., London, 92, 241-50.

Parsons, C.F. 1977. A stratigraphic revision of the Scarborough Formation. Proc. Yorks. geol. Soc., 41, 203-22, pls. 13-14.

Parsons, C.F. 1980. Aalenian and Bajocian Correlation Chart. In Cope, J.C.W. (Ed.), A correlation of Jurassic rocks in the British Isles. Part 2. Middle and Upper Jurassic, pp. 3-21. Geol. Soc. London.

Torrens, H.S. 1980. Jurassic stratigraphy in practice. In Cope, J.C. W. (Ed.), A correlation of Jurassic rocks in the British Isles. Part 1. Introduction and Lower Jurassic, pp. 2-4. Geol. Soc. London.

Wilson, J.L. 1975. Carbonate Facies in Geologic History. 471 pp. Berlin. 